\title{
ANTIMONY(V) AS ACCEPTORS
}

\author{
Ram Nath Prasad Yadav \\ Department of Chemistry, TU, Thakur Ram Multiple Campus, Birgunj, Nepal. \\ E-mail: ramnathy@rocketmail.com
}

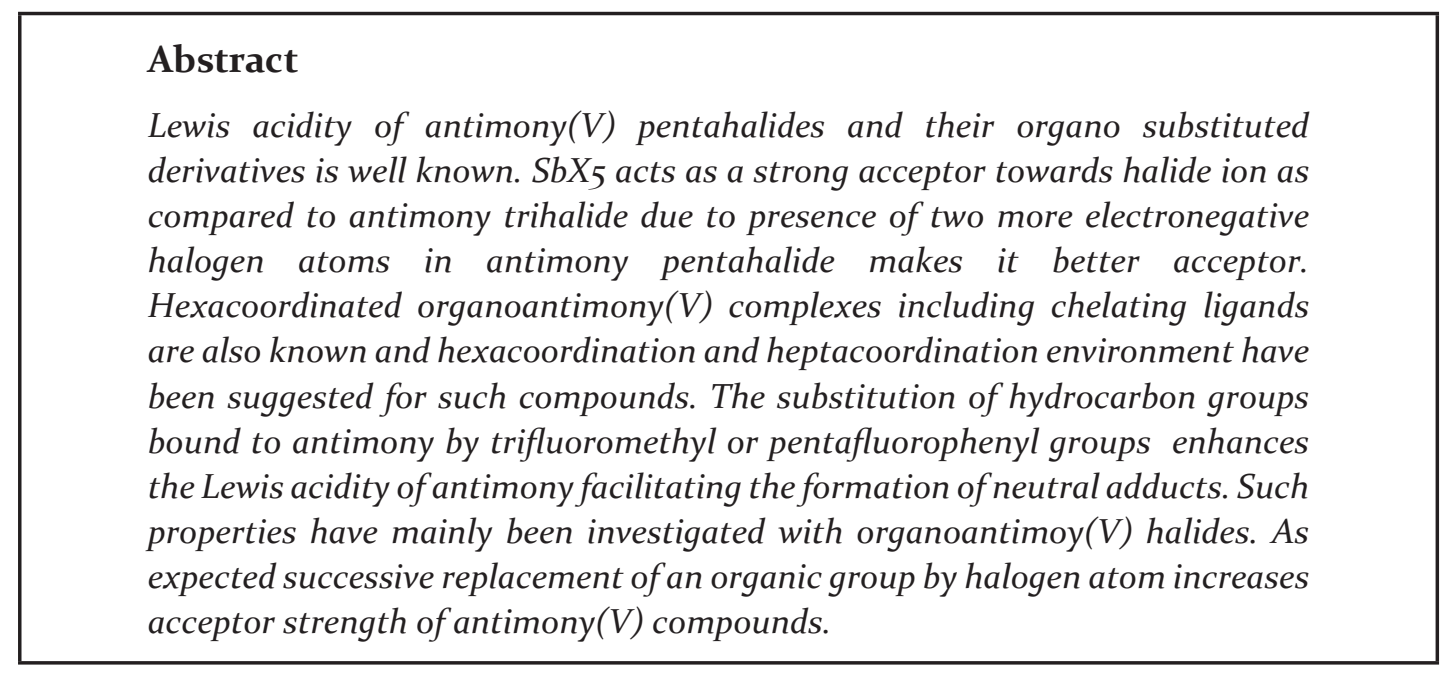

\section{Key words}

Antimony $(\mathrm{V})$; hexacoordinate; heptacoordinate; chelate; trifluoromethyl

\section{Introduction}

Lewis acidity of antimony $(\mathrm{V})$ pentahalides with a variety of Lewis bases which may be oxygen donors ( $\mathrm{Ph} P \mathrm{PO}, \mathrm{R}_{2} \mathrm{SO}, \mathrm{Cl}_{2} \mathrm{SO}$ ), sulphur donors $\left(\mathrm{R}_{2} \mathrm{~S}, \mathrm{RSH}\right)$, nitrogen donors $\left(\mathrm{C}_{5} \mathrm{H}_{5} \mathrm{~N}\right.$, $\mathrm{R}_{3} \mathrm{~N}$ ) and chlorine donors ( $\mathrm{NOCl}, \mathrm{TeCl}_{4}^{5}$, $\mathrm{Me}_{3}^{3} \mathrm{SbCl}_{2}$ ) has been reported and the majority of the adducts conform 1:1 stoichiometry (Abel et al. 1969). SbX act as acceptor towards halide ion forming the complex of the type $\mathrm{M}\left[\mathrm{SbX}_{6}\right]\left[\mathrm{M}=\right.$ alkali metal, $\mathrm{R}_{4} \mathrm{~N}^{+}$, in which antimony moiety acts as anion. Substitution of one or two chlorine atom(s) by phenyl group(s) in $\mathrm{SbCl}_{3}$ still leaves the molecules with acceptor properties. Substitution of three chlorine atoms by organic group also leaves the molecules with some acceptor properties provided that the substituted group should be strongly electronegative for e.g. $\left(\mathrm{CF}_{3}\right)_{3} \mathrm{SbCl}_{2}$ and $\left(\mathrm{C}_{6} \mathrm{~F}_{5}\right)_{3} \mathrm{SbCl}_{2}$ which form weak complexes with pyridine (Dale et al., 1957). Given below is summary of the complex forming tendency of antimony in its pentavalent state containing (mainly halide, $\mathrm{X})$ and organic groups $\mathrm{R}(\mathrm{R}=$ $\mathrm{CH}_{3}, \mathrm{C}_{6} \mathrm{H}_{5}, \mathrm{CF}, p-\mathrm{XC}_{6} \mathrm{H}_{4} ; \mathrm{X}=\mathrm{CH}_{3}, \mathrm{Cl}$, Br etc.). 


\section{Neutral complexes of organoantimony $(\mathrm{V})$ compounds}

Mono and dialkyl antimony(V) halides, $\mathrm{RSbX}_{4}$ and $\mathrm{R}_{2} \mathrm{SbX}_{3}$ are thermally unstable and decompose even at room temperature as such few studies have been made with these compounds (Poller, 1979). However, Nishii et al. have succeeded in stabilizing these compounds by substituting $\mathrm{X}$ atom with a chelating group or by adding an oxygen donor molecule and have studied the structure of resulting alkylantimony compounds (Nishii et al., 1969) together with those of corresponding aryl-antimony derivatives (Nishii et al., 1973). For example, for monomethyl antimony adducts, $\mathrm{CH}_{3} \mathrm{SbCl}_{4} \cdot \mathrm{L}\left(\mathrm{L}=\mathrm{PyO}\right.$ or $\left.4-\mathrm{CH}_{3} \mathrm{PyO}\right)$ in solution two isomeric forms (Fig.1) and (Fig. 2) were suggested to be in equilibrium from the solvent dependent PMR spectra. And for dimethylantimony adducts, $\left(\mathrm{CH}_{3}\right)_{2} \mathrm{SbCl}_{3} \cdot \mathrm{L}$ ( $\mathrm{L}$ = DMSO, HMPA, TPPO or PyO) in solution, an octahedral structure with trans-methyl configuration (Fig. 3) was suggested.
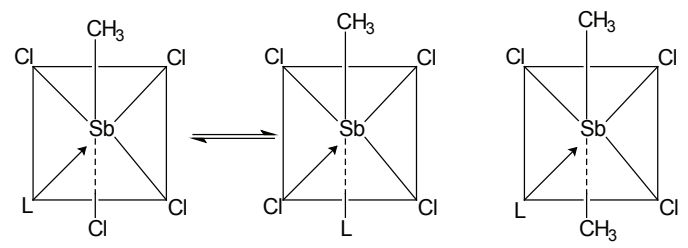

Fig: cis- $\left(\mathrm{CH}_{3}\right)_{2} \mathrm{SbCl}_{3}$. L adduct (1) Fig: trans- $\left(\mathrm{CH}_{3}\right)_{2} \mathrm{SbCl}_{3} \cdot \mathrm{L}$ adduct (2) Fig: trans- $\left(\mathrm{CH}_{3}\right)_{2} \mathrm{SbCl}_{3} \cdot \mathrm{L}(3)$

Hexacoordinated organoantimony $(\mathrm{V})$ complexes including chelating ligands such as acetylacetone (Me inema et al., 1972) and oxinate (Meinema et al., 1969) are also known. Organoantimony $(\mathrm{V})$ compounds, $\mathrm{R}_{\mathrm{n}} \mathrm{SbX}_{\mathrm{s}-\mathrm{n}}(\mathrm{n}$ $=2$ and 3) also form complexes with Schiff bases (Saxena et al.,1990). Hexacoordination and also heptacoordination environment have been suggested for organoantimony $(\mathrm{V})$ compounds of type $\mathrm{R}_{2} \mathrm{SbCl} . \mathrm{L}$ ( $\mathrm{L}=$ tridentate ligand with $\mathrm{ONO}$ donor system) and $\mathrm{R}$ SbL ( $\mathrm{L}=$ dibasic tetradentate ligand with $\mathrm{ONNO}$ donor system) suggesting figure (4 )and (5) respectively (Saxena et al., 1990).

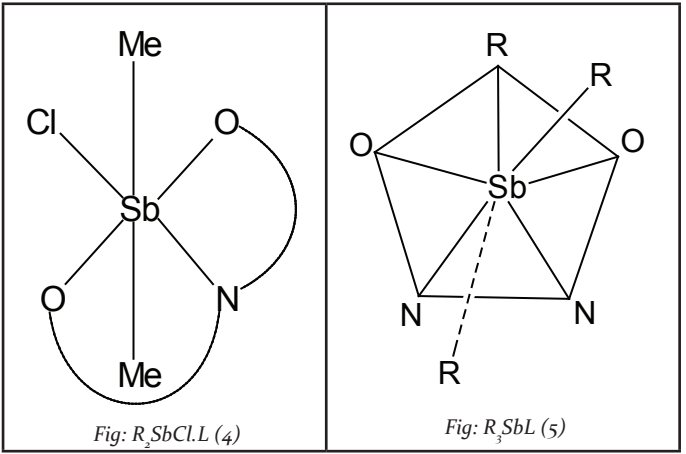

Gopinathan have also reported chelated organoantimony complexes of the types $\mathrm{Ph}_{3} \mathrm{SbL}_{2}, \quad \mathrm{LSbCl}_{4} \quad(\mathrm{~L}=$ Salicyladehyde, hydroxyquinoline, etc.).

The substitution of hydrocarbon group(s) bound to antimony by trifluoromethyl or pentafluorophenyl group(s) enhances the Lewis acid character of antimony facilitating the formation of neutral molecular adducts with oxygen, nitrogen and sulphur donor Lewis bases, for e.g., $\left(\mathrm{CF}_{3}\right)_{3} \mathrm{SbCl}_{2} \cdot \mathrm{Py}$ (TrotmanDickenson, 1973).

It is well established that Lewis acidity of the $\mathrm{R}_{\mathrm{n}} \mathrm{SbX} \mathrm{s}_{\mathrm{n}}$ derivatives in their reactions with various ligands as demonstrated by IR and NMR spectra increases with decreasing value of $n$. (Wardell, 1982). Such properties have mainly been investigated with orgnoantimony(V) halides (Okawara \& Matsumura, 1976). As expected successive replacement of an organic group by halogen results in increasing the acceptor strength of the antimony $(\mathrm{V})$ compounds. Thus Popov and Kondratenko have established the Lewis acidity sequences, as $\mathrm{RSbX}_{4}>\mathrm{R}_{2} \mathrm{SbX}_{3}>\mathrm{R}_{3} \mathrm{SbX}_{2}$ with neutral monodentate oxygen donor viz. DMSO molecular adducts of the type $\mathrm{RSbCl}_{4}$. DMSO and $\mathrm{R}_{2} \mathrm{SbCl}_{3}$. DMSO are readily isolated and their structure is established (Dale et al., 1957). Such complexes have octahedral environment around antimony. Schiff base complexes of diarganoantimony $(\mathrm{V})$ chlorides are also well known (Dibianca et al., 1973). 


\section{Anionic complexes of oraganoantimony $(V)$ halides}

Apart from neutral and chelated complexes of organoantimony $(\mathrm{V})$ compounds $\mathrm{R}_{\mathrm{n}} \mathrm{SbCl}_{5-\mathrm{n}}$ ( $n=1$ to 4 ), substantial work has reported on organoantimonates isolated in combination of bulkier cations. The anions $\left[\mathrm{R}_{\mathrm{n}} \mathrm{SbX}_{6-\mathrm{n}}\right]^{-1}(\mathrm{n}=1$ to 3) correspond to hexahalogenoantimonates, $\left[\mathrm{SbX}_{6}\right]^{-1}(\mathrm{X}=\mathrm{F}, \mathrm{Cl}$ or $\mathrm{Br})$ (Fisher \& Norman, 1994 and Hall \& Sowerby, 1988) as well as to the mixed species, $\left[\mathrm{SbCl}_{\mathrm{n}} \mathrm{F}_{6-\mathrm{n}}\right]^{-1}(\mathrm{n}=1$ to 5$)$ and $\left[\mathrm{SbCl}_{5} \mathrm{Br}\right]^{-1}$ obtained as solid salts of suitable cations (Bentley et al., 1972). The synthesis and spectral data of some compounds containing hexacoordinate organoantimony $(\mathrm{V})$ anions of the type $\left[\mathrm{ArSbX}_{5}\right]^{-1}(\mathrm{X}=\mathrm{Cl}, \mathrm{Br}$ or $\mathrm{F})$ have been reported (Bertazzi et al., 1975).

Dialkylantimony $(\mathrm{V})$ derivatives are considered to be thermally unstable. Only dimethyl antimony trihalides, $\mathrm{Me}_{2} \mathrm{SbX}_{3}$ (X $=\mathrm{Cl}, \mathrm{Br}$ ) have been isolated and were found to undergo a gradual decomposition at room temperature into $\mathrm{Me}_{2} \mathrm{SbX}$ and $\mathrm{MeX}$. These alkyl compounds can be made thermally stable by complexing with halide (Beattie et al., 1973) to form anion of the type $\left[\mathrm{Me}_{2} \mathrm{SbCl}_{4}\right]^{-}$ and also with Lewis base (Meinema \& Noltes, 1974) and mono-, bi- or tridentate ligands (Meinema \& Noltes, 1974).

Diarylantimony trichloride forms anions of the type $\left[\mathrm{Ar}_{2} \mathrm{SbCl}_{4}\right]^{-1}$ with amine hydrochloride (Doak et al., 1952) and diazonium chloride. These decompose in the range $74^{\circ}-170^{\circ} \mathrm{C}$ and it is claimed that decomposition temperature are sufficiently reproducible for characterization purposes. Campbell and White (1958), however, isolated and reported melting points for several unsymmetrical pyridinium tetrachlorodiarylantimonates $(\mathrm{V}), \quad\left[\mathrm{C}_{5} \mathrm{H}_{5} \mathrm{~N}\right] \quad\left[p-\mathrm{EtO}_{2} \mathrm{CC}_{6} \mathrm{H}_{4} \mathrm{SbArCl}_{4}\right](\mathrm{Ar}=$ $p$-tolyl, $p$-cyclohexylphenyl, 1-naphthyl or 3-diphenyl). The diazonium tetrachlorodia rylantimonates $(\mathrm{V}),\left[\mathrm{ArN}_{2}\right] \quad\left[\mathrm{Ar}_{2} \mathrm{SbCl}_{4}\right]$ have also been obtained by the reaction between diarylchlorostibine and an aryldiazonium tetrachloroferrate (III) or an aryldiazonium chloride.

$\mathrm{Ar}_{2} \mathrm{SbCl}+3 \mathrm{ArN}_{2} \mathrm{Cl}$
$\quad\left[\mathrm{ArN}_{2}\right]\left[\mathrm{Ar}_{2} \mathrm{SbCl}_{4}\right]+2 \mathrm{~N}_{2}+2 \mathrm{Ar} \ldots \ldots$ (1)

This reaction is in contradiction of an earlier work which indicates the formation of expected diazonium salts, $\left[\mathrm{ArN}_{2}\right],\left[\mathrm{Ar}_{2} \mathrm{SbCl}_{2}\right]$. Reutov and coworkers were unable to obtain such compounds under a variety of reaction conditions and they doubt if these substances are capable of existence.

Apart from synthesis of tetrachlorodiarylantimonate(V), $\quad\left[\mathrm{Ar}_{2} \mathrm{SbCl}_{4}^{-}\right]^{-1}, \quad$ Bertazzi et al. (Bertazzi et al. 1974) during their studies on the formation and structure of organoantimony $(\mathrm{V})$ complexes succeeded in the preparation of mixed chorohalogeno and mixed chloropseudohalogeno diphenyl antimonate(V) of the type $[\mathrm{M}(1)]\left[\mathrm{Ph}_{2} \mathrm{SbCl}_{3} \mathrm{X}\right]$ (Where $\mathrm{M}(1)=\mathrm{Me}_{4} \mathrm{~N}, \mathrm{X}=\mathrm{Cl}, \mathrm{Br}, \mathrm{N}_{3}$ or $\mathrm{M}^{3}(1)$ $\left.=\mathrm{Ph}_{4} \mathrm{As}, \mathrm{X}=\mathrm{NCS}\right)^{4}$. Subsequently, the same authors reported diphenylantimonates $(\mathrm{V})$ of the type $\left[\mathrm{Ph}_{4} \mathrm{As}\right]\left[\mathrm{Ph}_{2} \mathrm{SbX}_{4}\right]\left(\mathrm{X}=\mathrm{F}, \mathrm{Cl}, \mathrm{Br}, \mathrm{N}_{3}\right.$, NCS, $\left.\mathrm{X}_{4}=\mathrm{Cl}_{3}^{4} \mathrm{Br} \mathrm{Cl}_{3} \mathrm{~N}_{3}^{2}\right)($ Bertazzi 1976).

Meinema et al. (1977) have synthesized trichlorodiorganoantimony $(\mathrm{V})$ compounds. $\mathrm{R}_{2} \mathrm{SbX}_{3}$ in which the antimony atom is a part of a hetrocyclic ring and converted to the same compound into the corresponding tetramethylammonium tetrachlorodiorganoantimonates $\left[\mathrm{Me}_{4} \mathrm{~N}\right]$ [cis- $\left.\mathrm{R}_{2} \mathrm{SbCl}_{4}\right]$ which are hexacoordinated antimony $(\mathrm{V})$ species in which $\mathrm{Sb}-\mathrm{Cl}$ bonds are forced into cis-position as shown below.

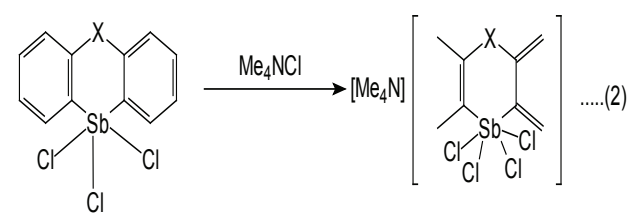

$$
\begin{array}{cl}
\text { Fig: } \mathrm{R}_{2} \mathrm{SbX}_{3}(16) & \text { Fig: }\left[\mathrm{Me}_{4} \mathrm{~N}\right] \text { [cis- } \\
& \left.\mathrm{R}_{2} \mathrm{SbCl}_{4}\right](17) \\
\left(\mathrm{X}=\mathrm{O}^{-}, \mathrm{CH}_{2}^{-},-\mathrm{CH}_{2} \mathrm{CH}_{2}-\right) &
\end{array}
$$

Beattie et al. (1973) proposed the structure of 
hexacoordinated diorganoantimony $(\mathrm{V})$ anion in the complex $\left[\mathrm{Me}_{4} \mathrm{~N}\right]\left[\mathrm{Me}_{2} \mathrm{SbCl}_{4}\right]$ by IR and Raman spectra from which an octahedral structure with trans organic groups has been deduced. Later on Bertazzi et al. (1976) established a similar structure for analogous $\left[\mathrm{Ph}_{2} \mathrm{SbX}_{4}\right]$ and $\left[\mathrm{Ph}_{2} \mathrm{SbCl}_{3}\right]^{-1}$ species $(\mathrm{X}=$ halogen or pseudohalogen) by Raman and Vibrational spectra.

A number of diarylantimonates(V) anionic complexes have been prepared and isolated with tetraalkylammonium, tetraphenylphosphoium and stibonium cations. Solution phase and spectroscopic studies were made to elucidate their structures.

The existence of the anionic complexes in the series of $\mathrm{R}_{3} \mathrm{SbX}_{2}$ could only be demonstrated, only when $\mathrm{R}=\mathrm{CF}_{3}$, for e.g., $\left[\mathrm{C}_{5} \mathrm{H}_{5} \mathrm{~N}\right]\left[\mathrm{R}_{3} \mathrm{SbCl}_{3}\right]$, $[\mathrm{NO}]\left[\mathrm{R}_{3} \mathrm{SbCl}_{3}\right]$ and $[\mathrm{H}]\left[\mathrm{R} \mathrm{Sb}_{3}(\mathrm{OH})_{3}\right]$.

\section{Cationic complexes of organoantimony $(V)$ compounds}

In sharp contrast to well documented neutral and anionic complexes of $\mathrm{R}_{\mathrm{n}} \mathrm{SbCl}_{5-\mathrm{n}}(\mathrm{n}=1$ to 4 ), reports on the isolation of cations of the type $\left[\mathrm{R}_{3} \mathrm{SbL}_{2}\right]^{+2}\left[\mathrm{R}_{2} \mathrm{SbL}_{3}\right]^{+3},\left[\mathrm{RSbL}_{4}\right]^{+4}$ are rather limited $(\mathrm{L}=$ Neutral $\mathrm{O}, \mathrm{N}, \mathrm{S}$, donor) (Wardell, 1982). The existence of complex cations of the type $\left[\mathrm{R}_{3} \mathrm{SbL}_{2}\right]^{+2}\left[\mathrm{R}_{3} \mathrm{SbL}-\mathrm{L}\right]$ and $\left[\mathrm{R}_{2} \mathrm{SbL}_{3}\right]^{+3}$ isolated in combination of bulkier anions viz., $\mathrm{BF}_{4}^{-}, \mathrm{BPh}_{4}^{-}, \mathrm{ClO}_{4}^{-}$etc. has been demonstrated by Goel \& Prasad (1973) and later on by Premraj et al. (1992 ${ }^{\mathrm{a}}$ ) and Premraj et al. $\left(1992^{\mathrm{b}}\right)$. In addition to these, cationic complexes of the types $\left.\left[\left(\mathrm{R} \mathrm{SbL}_{2}\right)_{2} \mathrm{O}\right]\left(\mathrm{ClO}_{4}\right)_{2}\right]$ and $\left[\mathrm{Ph}_{3} \mathrm{Sb}\left(\mathrm{H}_{2} \mathrm{O}\right)_{2} \mathrm{O}\left(\mathrm{ClO}_{4}\right)_{2}^{3}\right]$ are also known containing penta-coordinate cations (Goel \& Prasad, 1972). Only recently hexacoordinate complex cations of the type $\left[\mathrm{R}_{2} \mathrm{SbL}_{3}\left(\mathrm{OClO}_{4}\right)\right]$ $\left[\mathrm{ClO}_{4}\right]_{2}$ have been synthesised by Singhal and coworkers. However, reports on $\left[\mathrm{R}_{2} \mathrm{SbL}_{3}\right][\mathrm{Y}]_{3}$ where $\mathrm{Y}$ is $\mathrm{BF}_{4}, \mathrm{BPh}_{4}$ or $\mathrm{PF}_{6}$ are still lacking.

\section{Conclusion}

Complex formation tendency of antimony plays important role as result of this voluminous amount of work done on organo dervatives of antimony(V) such as anionic, cationic complexes and molecular adducts. However, a perusal of literature reveals that complex forming tendency of antimony $(\mathrm{V})$ halides is yet to be accomplished.

\section{Acknowledgement}

The author is thankful to the Head, Department of chemistry, Lucknow University and the Director, Regional Sophisticated Instrumentation Centre, CDRI, Lucknow for providing necessary library facilities. Thanks are also due to Dr. Premraj, Professor of Chemistry, Lucknow University, Lucknow India for his valuable suggestions.

\section{References}

Abel E.W., Crow J.P. and Illingworth S.M. (1969). Organosilicon and organotin phosphines and arsines as mono- and poly-dentate ligands to metal carbonyls. J. Chem. Soc. A, 1631-1633.

Beattie I.R., Stokes F.C. and Alexander L.E. (1973). Vibrational spectra of some chloro and methylchloro species of cadmium, indium, tin, antimony, tellurium and iodine. J. Chem. Soc. (Daltons). 465-469.

Bentley F.F., Finch A., Gates P.N. and Ryan F.J. (1972). Existence of chlorobromoantimoates. Inorg. Chem. 11(2), 413-414.

Bertazzi N., Pellerito L. and Stocco G.C.(1974). Mixed chlorohalogeno- and chloropseudohalogeno diphenylantimonates. Inorg. Nucl. Chem. Lett. $10(10), 855-858$.

Bertazzi N. (1976). Synthesis and low frequency vibrational spectra of some halo- and pseudohalo- diphenylantimonates $(\mathrm{V})$. J. Organomet. Chem. 110(2), 175-182.

Bertazzi N., Airoldi M. and Pellerito L. (1975). Complexes of organometallic compounds: XLIII. Synthesis and infrared spectra of fluoro-, 
chloro- and bromo-phenylantimonates(V). J.Organomet. Chem. 97(3), 399-403.

Campbell I.G.M. and White A.W. (1958). The stereochemistry of triarylstibines. Part II. Synthesis of unsymmetrically substituted triarylstibines and optical resolution of p-carboxyphenyl-1-naphthylphenylstibine: $J$. Chem. Soc.(Resumed). 1184-119o.

Dale J.W., Emeleus H.J., Haszeldine R.N. and Moss J.H. (1957). Organometallic and organometalloidal fluorine compounds. Part XIII. Trifluoro methyl derivatives of antimony. J. Chem. Soc.(Resumed). 3708-3713.

Dibianca F., Spek A.L., Meinema H.A. and Noltes J.G. (1973). Investigation on organoantimony compounds: XI. Triorganoantimony(V) compounds containing potentially tridentate ligands. J. Organomet . Chem. 63, 293-300.

Doak G.O., Freedman L.D. and Efland S.M. (1952). The reaction between diazonium fluoborates and antimony trichloride in organic solvents. J. Amer. Chem. Soc. 74(3), 830-831.

Fisher G.A. and Norman N.C. (1994). The Structures of the Group 15 Element(III) Halides and Halogenoanions. Adv. Inorg. Chem. 41, 233-271.

Goel R.G. and Prasad H.S. (1972). Organoantimony compounds. VI. Oxybis(triorganoantimony) diperchlorates and their complexes with oxygen-donor Lewis bases. Inorg. Chem. 11(9), 2141-2145.

Goel R.G. and Prasad H.S. (1973). Organoantomony compounds: VII. Preparation and characterization of complex triorganoantimony $(\mathrm{V})$ cations, $\mathrm{R}_{3} \mathrm{SbL}_{2}^{+2}$. J. Organomet, Chem. 59, 253-257.

Hall, M., and Sowerby, D.B. (1988). Phenylchloroantimo(III)nates; their preparation and the crystal structure of $\mathrm{Me}_{4} \mathrm{~N}\left[\mathrm{PhSbCl}_{3}\right], \quad[\mathrm{Hpy}]_{2}\left[\mathrm{PhSbCl}_{4}\right]$ and $\mathrm{Me}_{4}^{4} \mathrm{~N}\left[\mathrm{Ph}_{2} \mathrm{SbCl}_{2}\right]$. J. Organomet. Chem. 347, 5970.

Meinema H.A., Rivarola E. and Noltes J.G. (1969). Investigations on organoantimony compounds II. Preparation and configuration of organo(oxinato) antimony(V) compound $\mathrm{R}_{\mathrm{n}} \mathrm{SbCl}_{4-\mathrm{n}} \mathrm{O}_{\mathrm{x}}(\mathrm{n}=1-4)$. J. Organomet. Chem. $17(1)$, 71-81.

Meinema H.A., Mackor A. and Noltes J.G. (1972). Investigations on organoantimony compounds: VII. The stereochemistry of (acetylacetonato) organoantimony $(\mathrm{V})$ compounds, $\mathrm{R}_{\mathrm{n}} \mathrm{SbCl}_{(4-\mathrm{n})}$ Acac $(\mathrm{n}=1-4)$. J. Organomet. Chem. 37(2), 185295 .

Meinema H.A. and Noltes J.G. (1974). Some aspects of organoantimony coordination chemistry. Ann. N.Y. Acad. Sci. 239, 278-291.

Meinema H.A. (1977). Investigations on organoantimony compounds: XVI. Preparation and properties of hetrocyclic trichloro-cisdiorganoantimony $(\mathrm{V})$ compounds and of the corresponding tetramethyl- ammonium tetrachlorodiorganoantimonates. J. Organomet. Chem. 136(2), 173-184.

Nishii N., Shindo M., Matsumura Y. and Okawara R. (1969). Stable mono- and dimethylantimony(V) compounds. Inorg. Nucl. Chem. Lett. 5(7), 529-530.

Nishii N., Hashimoto K. and Okawara R. (1973). Preparation and properties of monoorganoantimony tetrachloride adducts. J. Organomet. Chem. 55(1), 133-137.

Okawara R. and Matsumura Y. (1976). Recent advances in organoantimony chemistry. $A d v$. Organometallic Chem.14, 187-204.

Poller R.C. (1979). Organic compounds of antimony and bismuth. In Barton and W.D. Ollis (eds) Comprehensive organic chemistry Vol. 3. Oxford: Pergamon Press.

Premraj and Agrawal A.K. $\left(1992^{a}\right)$. Synthesis and characterization of the complex triorganoantimony $(\mathrm{V})$ cations, $\mathrm{R}_{3} \mathrm{SbL}^{+2}$ and $\mathrm{R}_{3} \mathrm{Sb}(\mathrm{L}-\mathrm{L})^{+2}$. Synth. React. Inorg. Met-Org. Chem. 22(5), 543-457.

Premraj, Agrawal A.K. and Singhal K. $\left(1992^{\mathrm{b}}\right)$. Synthesis and geometry of complex triorganoantimony $(\mathrm{V})$ cations. Synth. React. Inorg. Met-Org. Chem. 22(10), 1471-1494. 
Saxena A.K., Premraj and Dixit S.K. (1990). Preparation and and structure of some substituted tertiaryaryl antimony $(\mathrm{V})$ complexes of tetra dentate Schiff bases. Synth. React. Inorg. Met. Org. Chem. 20(2), 199-208.

Singhal K., Yadav R.N.P., Premraj and Agarwal A.K. (2003). On the Lewis tris(pentafluorophenyl) antimony $(\mathrm{V})$ dichloride towards neutral monodentate $\mathrm{O}, \mathrm{N}$ and $\mathrm{S}$ donor ligands. J. Fluorine Chem. 121, 131-134.
Trotman-Dickenson A.F. (1973). Comprehensive Inorganic Chemistry. New York: Pergamon Press.

Wardell, J.L. (1982). Arsenic, Antimony and Bismuth. In G. Wilkinson, F.G.A. Stone \& E.W. Abel, (eds) Comprehensive organometallic chemistry. New York: Pergamon press. 